\title{
Analysis and Design of Administrative Data Management Using an Elicitation Approach (Case Study: LKP Putra Putri Indonesia)
}

\author{
${ }^{1}$ Arif Saripudin, ${ }^{2}$ Cecep Kurnia Sastradipraja, ${ }^{3}$ Falentino Sembiring \\ ${ }^{123}$ Sistem Informasi, Universitas Nusa Putra, Indonesia \\ ${ }^{1}$ arif.saripudin@gmail.com ${ }^{2}$ cecep.kurnia@nusaputra.ac.id, ${ }^{3}$ falentino.sembiring@nusaputra.ac.id
}

\section{ARTICLE INFO}

Article History:

Received : 03-09-2020

Revised : 25-11-2020

Accepted : 29-11-2010

Online : $\quad 30-11-2020$

Keywords:

Administration;

Elicitation Approach

Technique;

System Evaluation.

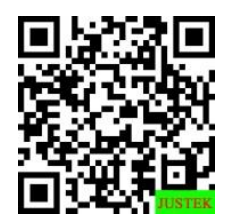

ABSTRACT

Abstract: This research aims to analyze and design an administrative data management information system in LKP3I, which currently manages it is still manual, namely using Ms. Excel office tools, so it often experiences problems such as accumulation of documents, difficulty finding data, and scattered data of course participants. The application development process using the waterfall model includes collecting data and information, at the analysis stage using the elicitation approach technique which is represented by system modeling, namely flow maps, context diagrams, and data flow diagrams. Construction of web-based application systems using the programming languages VB.Net and Ms. Access as database management system, testing and evaluating the feasibility of the system using the BlackBox and group discussions. Based on the results of the research and system evaluation conducted, the prototype of the LKP3I administrative data management system that was built through the elicitation approach received a fairly good assessment, which proves that the hypothesis in this study has been tested. Respondents can receive the results of the information system prototype that will be implemented with the provision of improved specifications and functions of user requirements.
\end{abstract}

\begin{abstract}
Abstrak: Penelitian ini bertujuan untuk menganalisis dan merancang sistem informasi pengelolaan data administrasi di LKP3I yang saat ini proses pengelolaannya masih manual yaitu menggunakan alat bantu perkantoran Ms. Excel, sehingga sering mengalami kendala seperti penumpukan dokumen, kesulitan mencari data, dan data peserta kursus yang berserakan. Proses pengembangan aplikasi dengan menggunakan model waterfall meliputi pengumpulan data dan informasi, pada tahapan analisis menggunakan teknik pendekatan elisitasi yang direpresentasikan melalui pemodelan sistem yaitu diagram alir dokumen, diagram konteks, dan diagram alir data. Konstruksi sistem aplikasi berbasis web dengan menggunakan bahasa pemrograman VB.Net dan Ms. Access sebagai pengelolaan database, pengujian dan evaluasi kelayakan sistem menggunakan BlackBox dan diskusi grup. Berdasarkan hasil penelitian dan evaluasi sistem yang dilakukan bahwa prototipe sistem pengelolaan data administrasi LKP3I yang dibangun melalui pendekatan elisitasi mendapat penilaian yang cukup baik, yang membuktikan bahwa hipotesis dalam penelitian ini telah teruji. Responden dapat menerima hasil dari prototipe sistem informasi yang akan diimplementasikan dengan ketentuan perbaikan spesifikasi dan fungsi kebutuhan pengguna.
\end{abstract}




\section{A. LATAR BELAKANG}

Laporan Daya Saing Global atau Global Competitiveness Report (GCR) merupakan sebuah laporan tahunan yang diterbitkan oleh World Economic Forum (WEF)(Muchdie, 2016), dimana pada tahun 2019 hasil rilis menunjukan bahwa daya saing global indonesia turun dan berada pada peringkat ke-50 (lima puluh) dunia, dari yang sebelumnya posisi ke-45 (empat puluh lima) dari 141 negara, dengan skor 64,6 (Schwab, 2019). Hal ini bukanlah merupakan kabar baik untuk mewujudkan sumber daya manusia yang unggul. Menurut Didin (Muhammad Syahrul Ramadhan, 2020) "Rendahnya peringkat indonesia dikarenakan Human Capital (Sumber Daya Manusia) dan ekosistem untuk berinovasi yang dinilai masih kurang kompetitif. Kekurangn tersebut, masih bisa diperbaiki dengan meningkatkan kualitas akses pendidikan". Ini adalah bentuk fakta yang menunjukan bahwa SDM Indonesia memiliki hubungan yang erat dengan mutu pendidikan atas institusi pendidikan yang ada di Indonesia.

Pada era globalisasi sekarang ini system informasi sangatlah penting dalam suatu perusahaan atau lembaga (Prastya et al., 2020). Sistem informasi dari satu bagian saling terkait dengan bagian lainnya (Rachmanto, 2017), sehingga informasi yang diberikan suatu bagian mempengaruhi aktivitas pada bagian yang lainnya. Sistem Informasi yang cepat, tepat dan terintegrasi akan memperlancar semua proses pada bagian terkait yang ada dalam suatu perusahaan atau lembaga (Wijaksana, 2015).

Ketersediaan informasi dan berjalannya komunikasi tidak terlepas dari dukungan komputer sebagai alat bantu untuk mempermudah pekerjaan (A et al., 2013). Disamping itu penggunaan komputer pada sebuah institusi mampu meningkatkan kualitas layanan (Sugandi, 2014) dan efisiensi kerja. Dalam setiap organiasi atau institusi pendidikan pasti memiliki ketersediaan sistem informasi yang digunakan, baik itu yang sudah terkomputerisasi atau masih menggunakan alat bantu seperti aplikasi perkantoran, seperti halnya pada Lembaga Kursus dan Pelatihan Putra-Putri Indonesia (LKP3I) Sukabumi.

Lembaga Kursus dan Pelatihan Putra-Putri Indonesia (LKP3I) adalah Lembaga Pelatihan Kerja yang didirikan dengan spirit dalam memajukan generasi anak bangsa dalam berkarya di Negeri Sakura, Jepang. Aktivitas utama dari LKP3I adalah penempatan tenaga kerja ke luar negeri dengan pelatihan utama yaitu pelatihan bahasa, budaya dan etos kerja. LKP3I bergerak dibidang pembelajaran Bahasa Jepang untuk Umum dan Program Pemagangan ke Jepang.

LKP3I dalam pengelolaan data administrasi pendidikannnya masih bersifat manual yaitu menggunakan alat bantu perkantoran seperti ms. Excel dan dalam sistem pemasaran masih dilakukan secara konvensional yaitu strategi marketing melalui "Word of Mouth" (WOM). Tidak sedikit kendala yang dihadapi pegawai ketika sistem belum dibangun secara terkomputerisasi atau belum memiliki sebuah system manajemen basis data, seperti halnya bertumpuknya berkas atau dokumen, sulit untuk melakukan pencarian data, data-data peserta pelatihan atau kursus sering berserakan seperti foto, data peserta, dan lain sebagainya. 
Mengacu pada permasalahan yang dihadapi LKP3I tersebut, maka dalam penelitian ini penulis mencoba untuk menganalisis dan membangun sebuah sistem informasi pengelolaan data administrasi kursus dan pelatihan keterampilan secara terkomputerisasi dengan menggunakan pendekatan elisitasi. Adapun pendekatan ini dilakukan berdasarkan hasil analisis sistem dan studi observasi yang dilakukan, dengan maksud dan tujuan untuk menghasilkan prototipe sistem informasi yang dapat mempermudah dalam penyelenggaraan pelatihan kerja di LKP3I.

\section{B. METODE PENELITIAN}

Tahapan pada sebuah penelitian dilaksanakan dengan tujuan untuk mencapai hasil yang maksimal. Adapun tahapan atau bagan alir penelitian tentang kajian analisis dan perancangan pengelolaan data administrasi pada LKP3I dapat dilihat pada Gambar 1 di bawah ini.

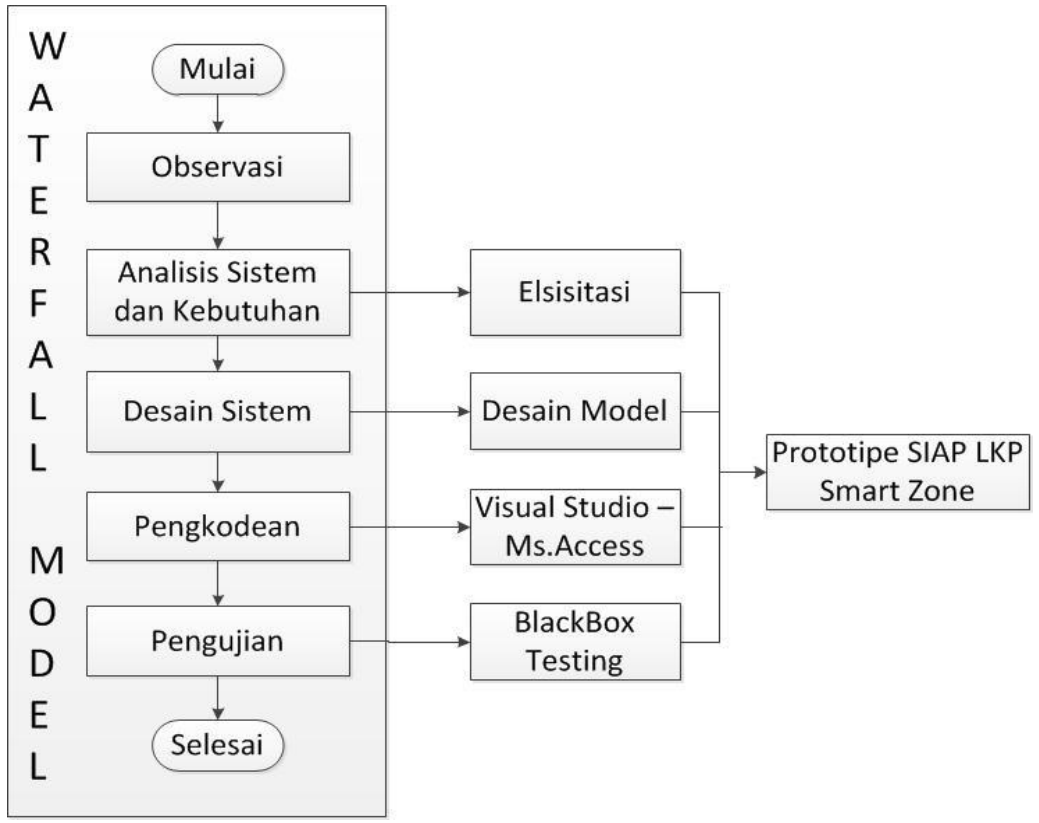

Gambar 1. Tahapan Penelitian

Dalam mengembangkan suatu sistem informasi diperlukan adanya persiapan dan perencanaan (Kurniawan, 2018), dimana hal ini memerlukan data-data dan informasi untuk mendukung terlaksananya penelitian. Metode yang digunakan pada tahap pengumpulan data dan informasi adalah studi literatur yaitu dengan mengumpulkan data-data yang ada relevansinya dengan topik permasalahan yang bersifat teoritis dengan cara membaca buku, jurnal, dan dokumen LKP3I.

Studi observasi dilakukan untuk mengetahui bagaimana sistem informasi yang sedang berjalan saat ini dalam pengelolaan data administrasi di LKP3I dan menganalis kebutuhan system yang diharapkan kedepannya melalui teknik pendekatan elisitasi.

Teknik wawancara secara terbuka dilakukan dengan pemilik atau pimpinan LKP3I beserta pengelola atau manajemen dari lembaga tersebut. Tahap perancangan sistem informasi merupakan transformasi dari hasil analisis yang dilakukan dengan menuangkannya ke dalam pemodelan system dengan menggunakan diagram alir dokumen, diagram konteks, dan diagram alir data. Konstruksi pembangunan perangkat 
lunak berbasis desktop menggunakan VB.Net, manajemen basis data menggunakan MySQL, Crystal Report untuk pelaporannya.

Pada tahapan pengujian sistem menggunakan teknik blackbox, dan evaluasi uji kelayakan sistem menggunakan teknik diskusi grup dengan responden yaitu Pimpinan dan Manajemen LKP3I.

\section{HASIL DAN PEMBAHASAN}

\section{Perancangan Sistem}

\section{a. Analisis Kebutuhan Sistem}

Tahapan analisa dari kebutuhan sistem informasi administrasi LKP3I ini menggunakan metode elisitasi, dengan metode ini maka perancangan sistem berdasarkan keinginan client atau manajemen yang disanggupi penulis (PRASTOMO, 2015). Yang diharapkan mampu menjawab dari permasalahan client dalam pengelolaan data administrasi LKP3I yang ada saat ini. Adapun elisitasi tahap 5 (final elisitasi) tertuang pada Tabel 1.

Tabel 1. Elisitasi Tahap 5

\begin{tabular}{|l|l|}
\hline \multicolumn{2}{|c|}{ Final Elisitasi (Tahap-5) } \\
\hline No. & \multicolumn{1}{|c|}{ Kebutuhan Sistem (Functional Requirement) } \\
\hline 1. & Menampilkan informasi jurusan \\
\hline 2. & Menampilkan informasi data instruktur \\
\hline 3. & Menampilkan informasi data peserta \\
\hline 4. & Menampilkan informasi mata pelajaran \\
\hline 5. & Menampilkan informasi jadwal pelatihan kursus \\
\hline 6. & Menampilkan laporan keuangan \\
\hline 7. & Menampilkan informasi biaya pelatihan \\
\hline 8. & Menampilkan laporan hasil Pembelajaran atau KBM \\
\hline 9. & Menyimpan data peserta kursus \\
\hline 10. & Menyimpan data pembayaran peserta \\
\hline 11. & Menyimpan data instruktur \\
\hline No. & Kebutuhan Sistem (Non Fuctional Requirement) \\
\hline 12. & Interface aplikasi mudah untuk diakses \\
\hline 13. & Sistem mudah untuk digunakan \\
\hline
\end{tabular}


b. Flowmap (Usulan)

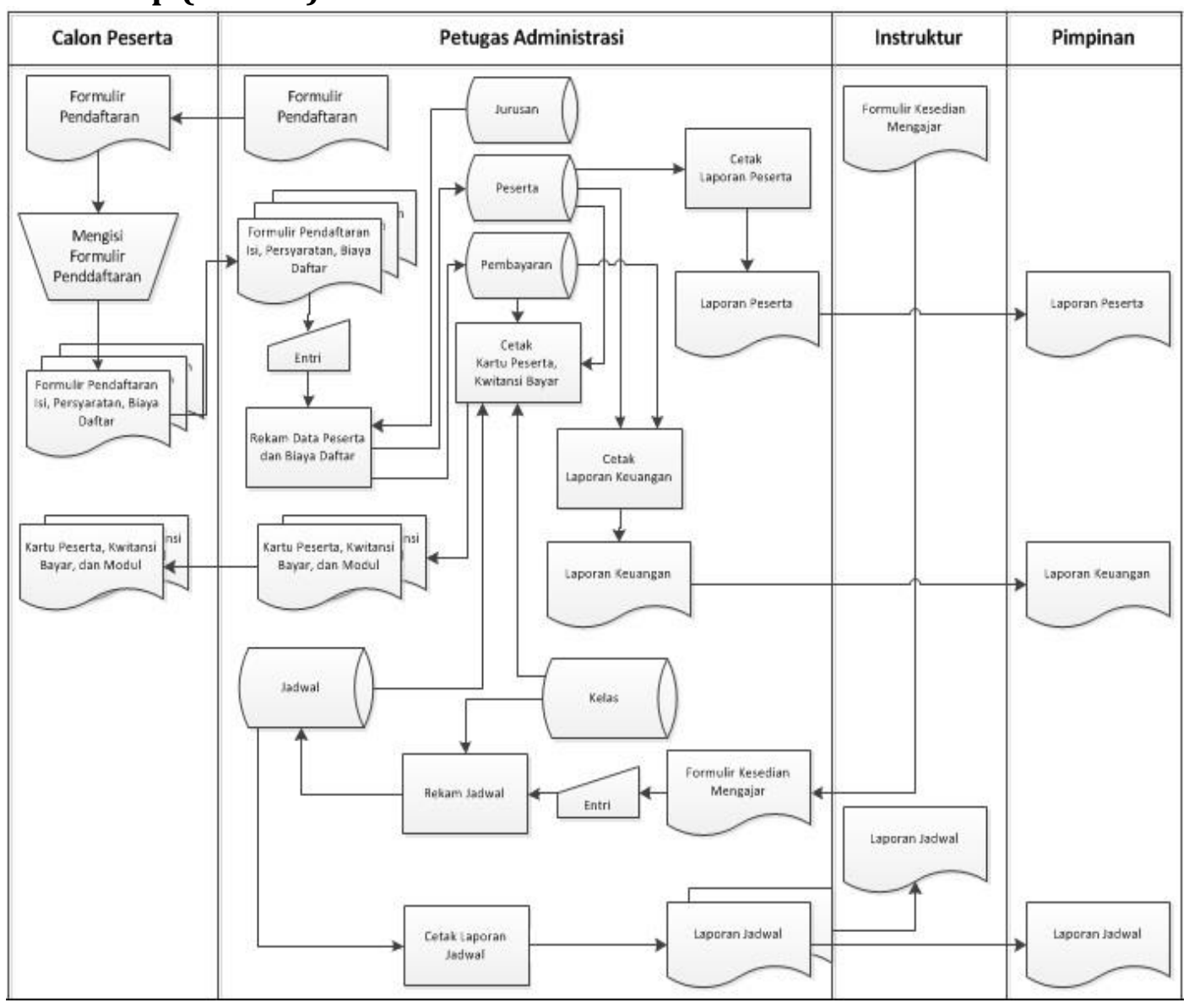

Gambar 2. Flowmap usulan

\section{c. Diagram Konteks (Usulan)}

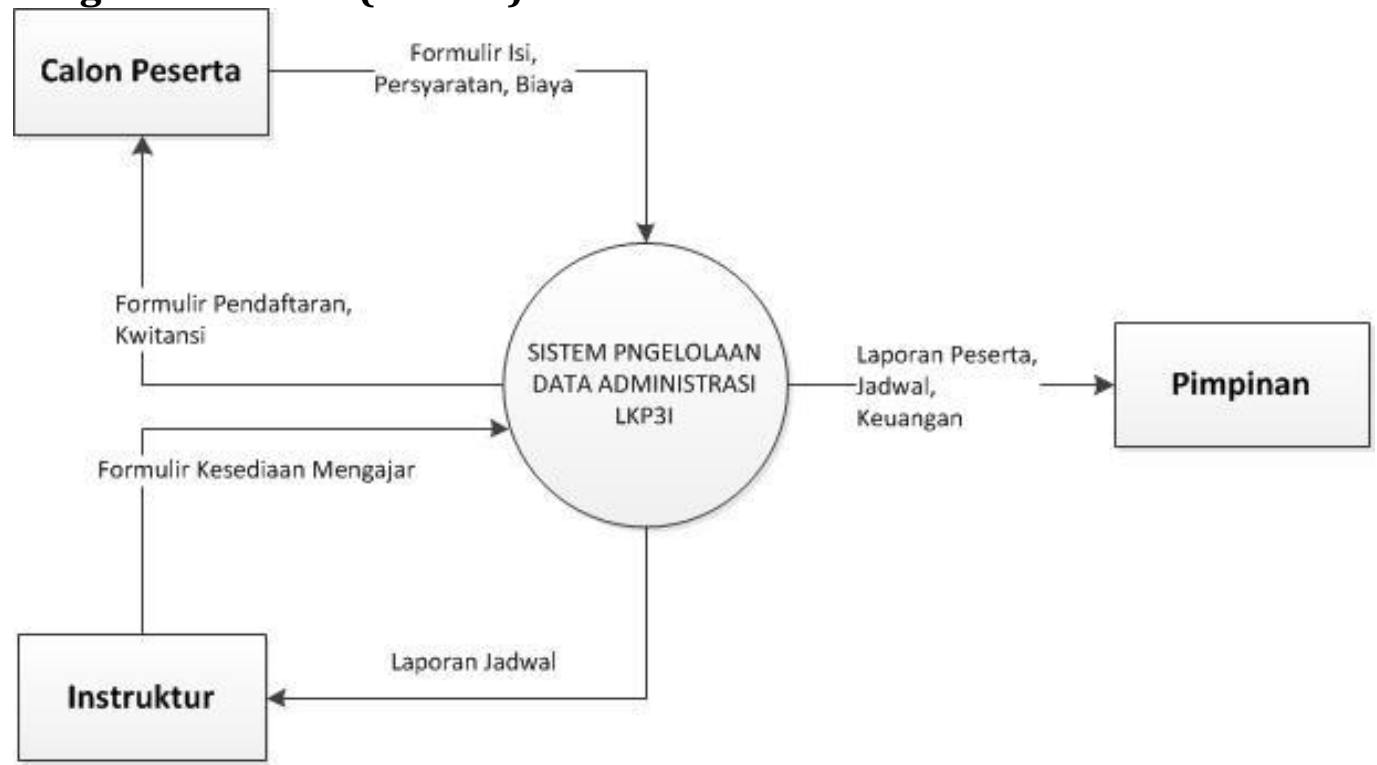

Gambar 3. Diagram konteks sistem yang diusulkan 


\section{d. Data Flow Diagram (Usulan)}

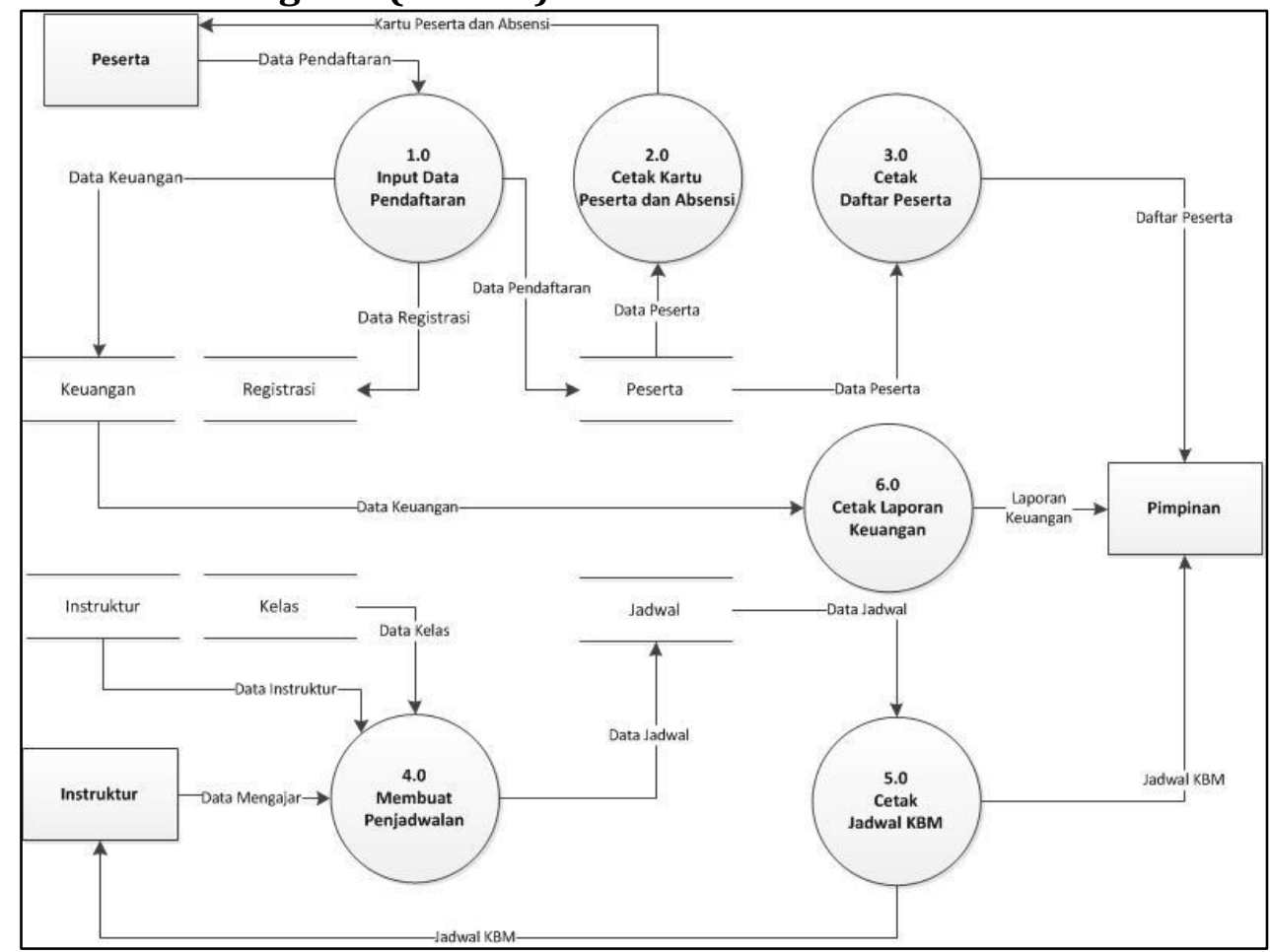

Gambar 4. DFD level 1 sistem yang diusulkan

\section{e. Entity Relationship Diagram}

Entity Relationship (E-R) Model merupakan representasi grafis dari logika basis data disertai keterangan lengkap tentang keseluruhan entitas, hubungan, dan batasan (Solikhin et al., 2018). Pada gambar 5 berikut ini adalah diagram E-R dari relasi antar entitas pada perancangan sistem yang dibangun.

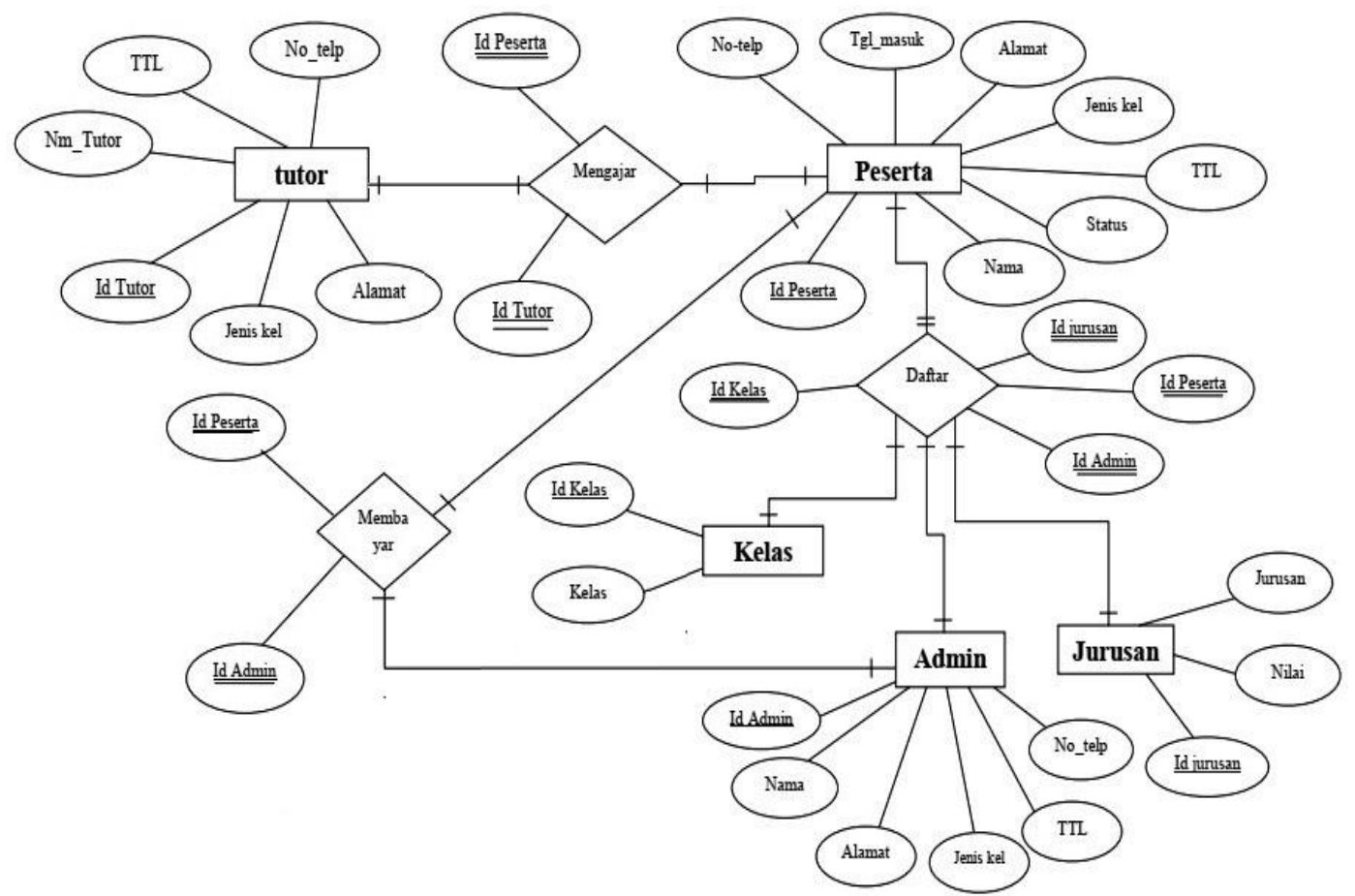

Gambar 5. ERD sistem yang diusulkan 


\section{f. Struktur Menu Aplikasi}

Struktur menu merupakan gambaran dalam bentuk diagram mengenai struktur menu program yang akan dibuat (Nugroho \& Sofyan, 2011). Struktur dari program yang dibuat adalah seperti pada gambar 6 berikut:

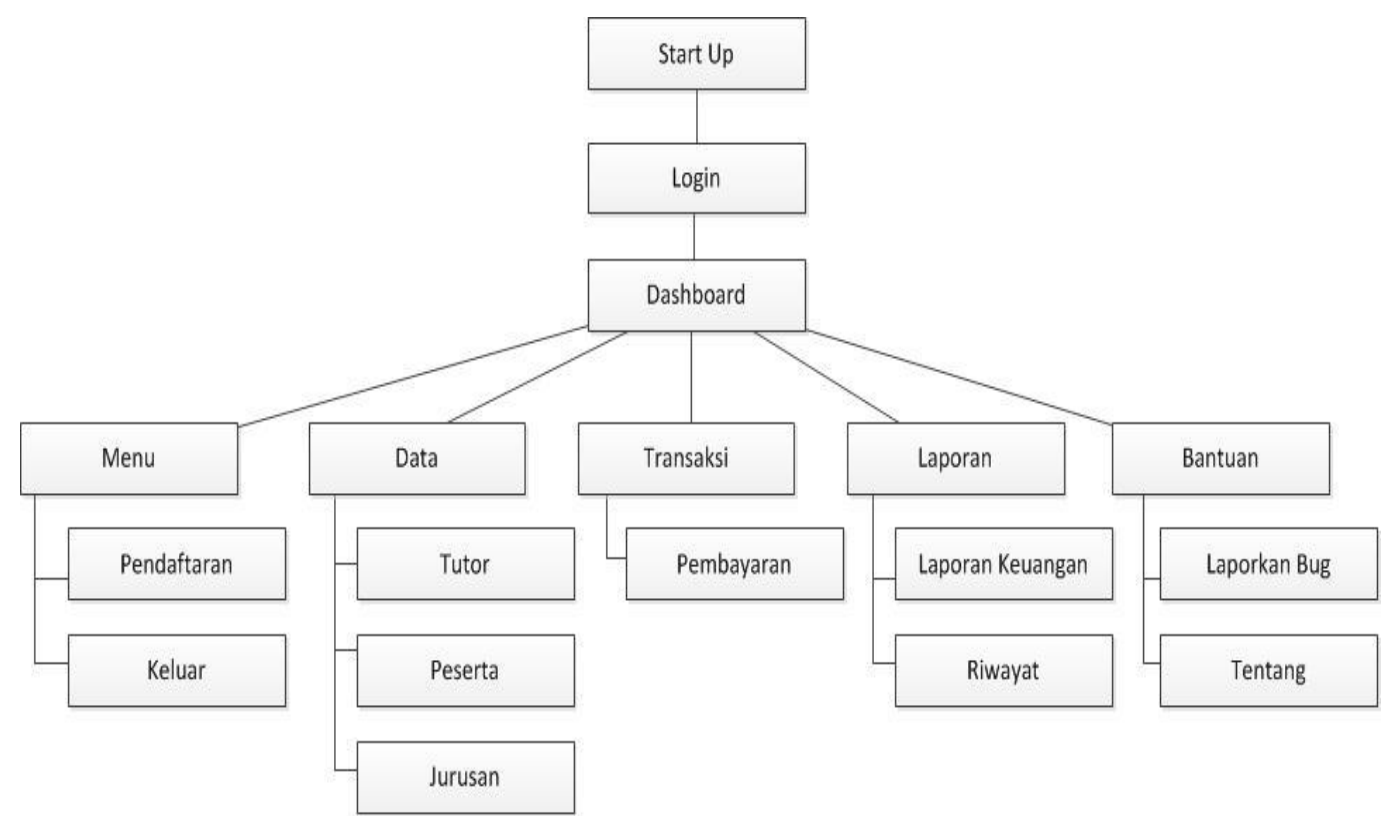

Gambar 6. Struktur Menu Aplikasi

\section{g. Kodifikasi}

Rancangan sistem pengkodean ini dibuat untuk mengidentifikasi suatu objek secara singkat, melalui sistem pengkodean ini diharapkan dapat mengklasifikasikan data. Kode dapat dibentuk dari kumpulan huruf, angka dan karakter khusus (Azis, 2018). Dalam perancangan kodifikasi sistem, penulis melakukan pengkodean sebagai berikut:

\section{Kode Peserta Kursus}

\section{ID XXXX}

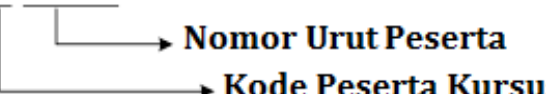

Contoh : ID0005

Keterangan :

ID $\quad=$ Kode Peserta

$05=$ Nomor peserta adalah 5

2. Kode Tutor

\section{T XXXX}

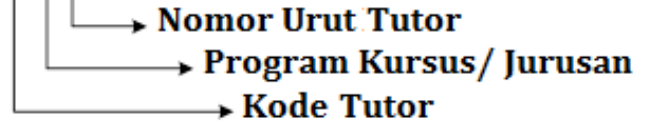

Contoh : T1005

Keterangan :

$\mathrm{T}=$ Kode Tutor

$1=$ Kode Program /Jurusan

$005=$ Nomor urut Tutor 
8 | Justek : Jurnal Sains dan Teknologi | Vol. 3, No. 2, November 2020, Hal. $01-16$

3. Kode Jurusan

JXXXX

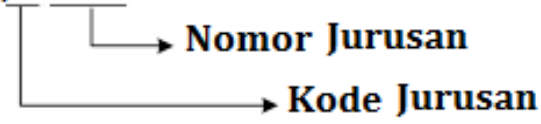

Contoh : J1003

Keterangan :

$\mathrm{J} 1=$ Kode Untuk Jurusan

003 = Nomor Urut Jurusan/ Program Kursus

4. Kode Transaksi Pembayaran

TRXXXX

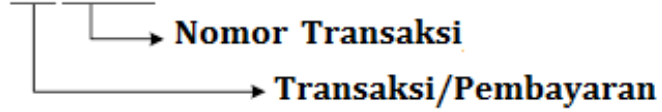

Contoh : TR0005

Keterangan :

TR = Kode Untuk Transaksi Pembayaran

0005 = Nomor Urut Transaksi

5. Kode Kelas

KXxX

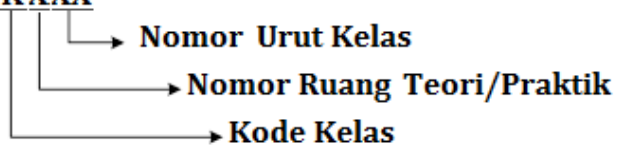

Contoh : K102

Keterangan :

$\mathrm{K}=$ Kode Untuk Kelas

$1=$ Nomor Urut Ruang Teori atau Praktik

$02=$ Nomor Urut Kelas

h. Perancangan Input

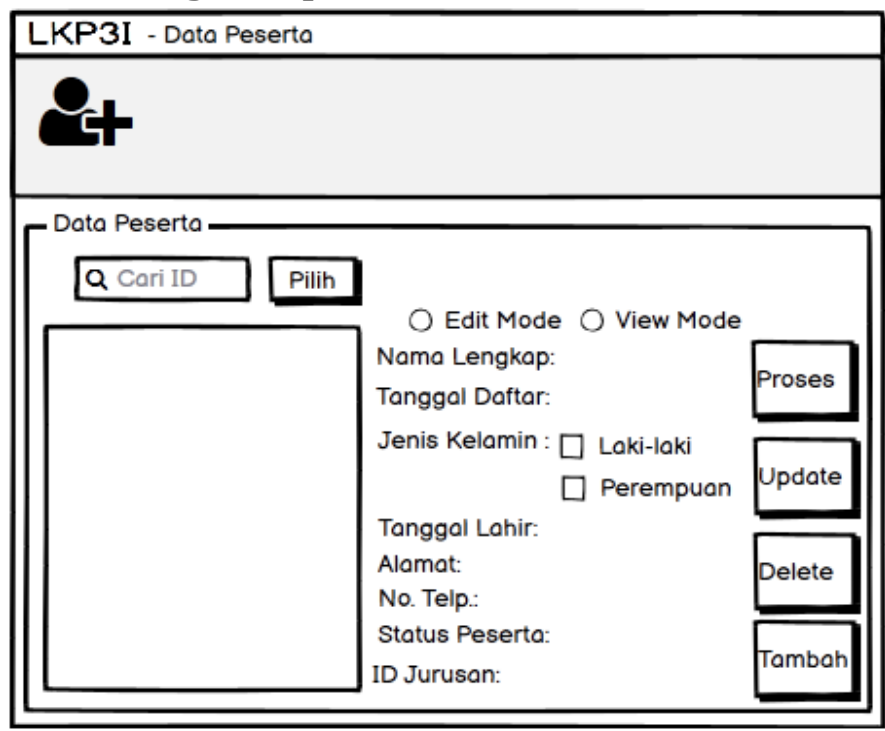

Gambar 7. Input peserta 


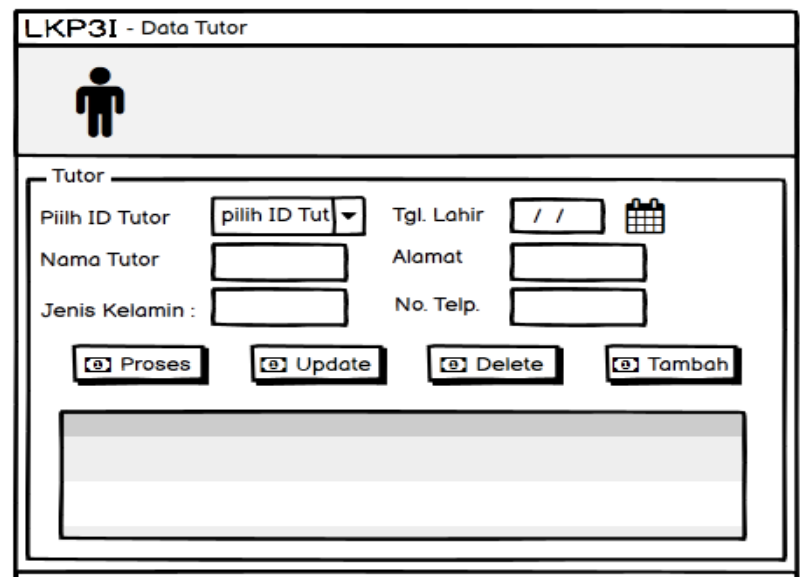

Gambar 8. Input Instruktur

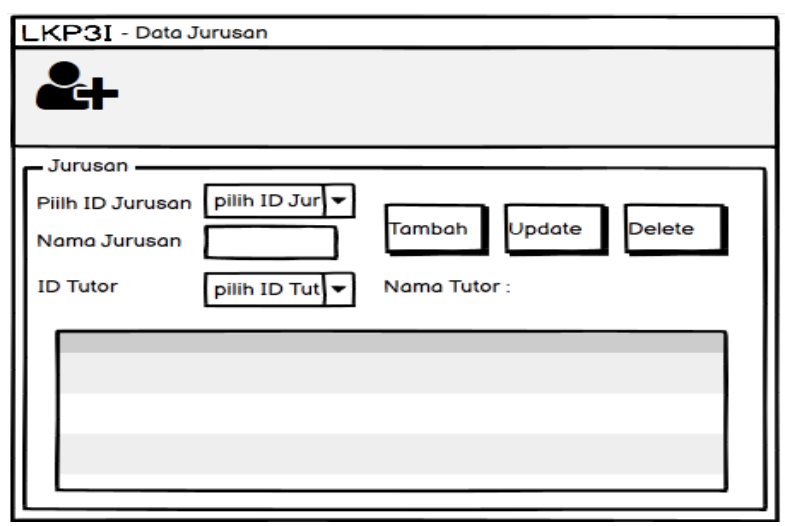

Gambar 9. Input Jurusan

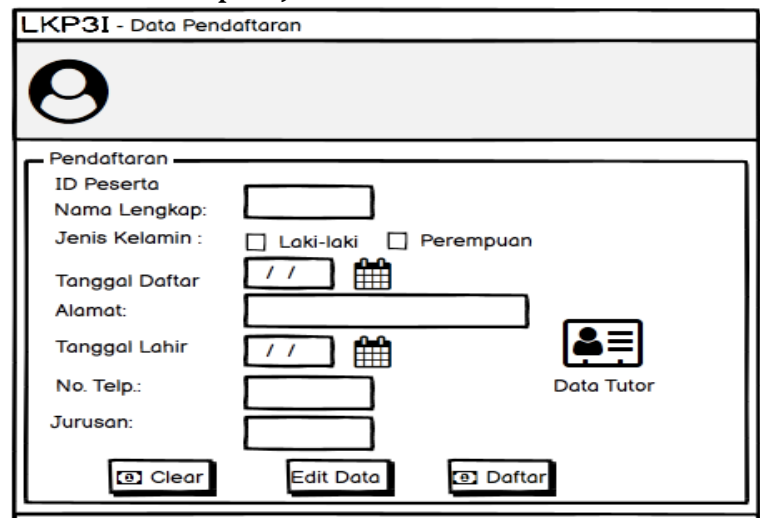

Gambar 10. Input Pendaftaran

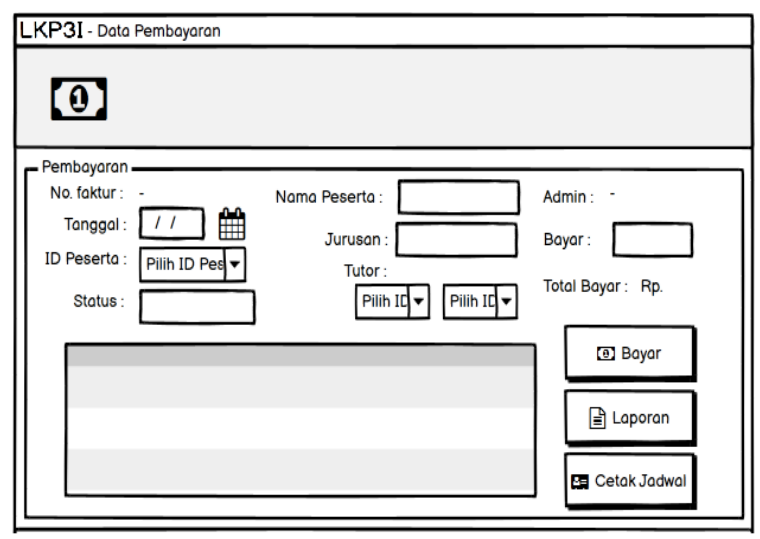

Gambar 11 Input Pembayaran 


\section{i. Perancangan Output}

Perancangan output yaitu perancangan model untuk pelaporan atau dokumen sebagai format keluaran dari aplikasi (wahyu timortiingsih, 2011). Adapun perancangan keluaran untuk sistem informasi administrasi pendidikan pada LKP3I seperti pada gambar 12 berikut:

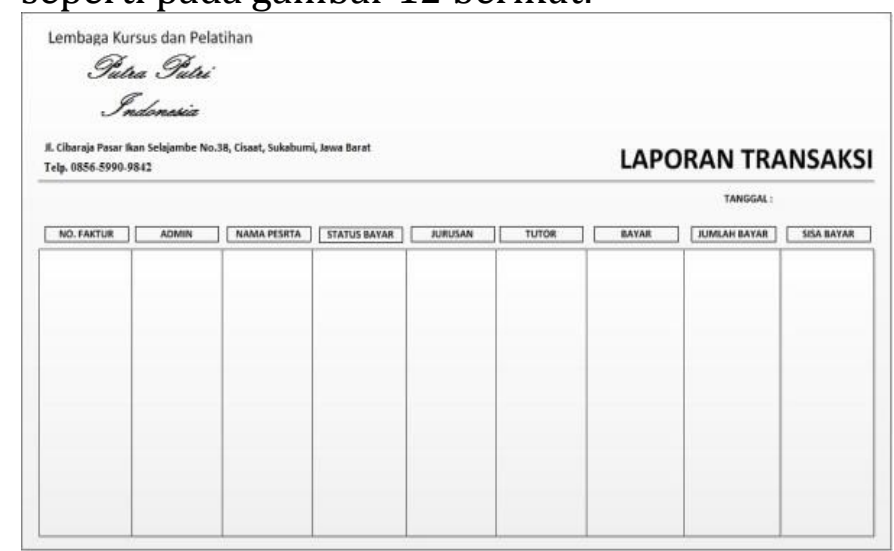

Gambar 12. Laporan Transaksi Pembayaran

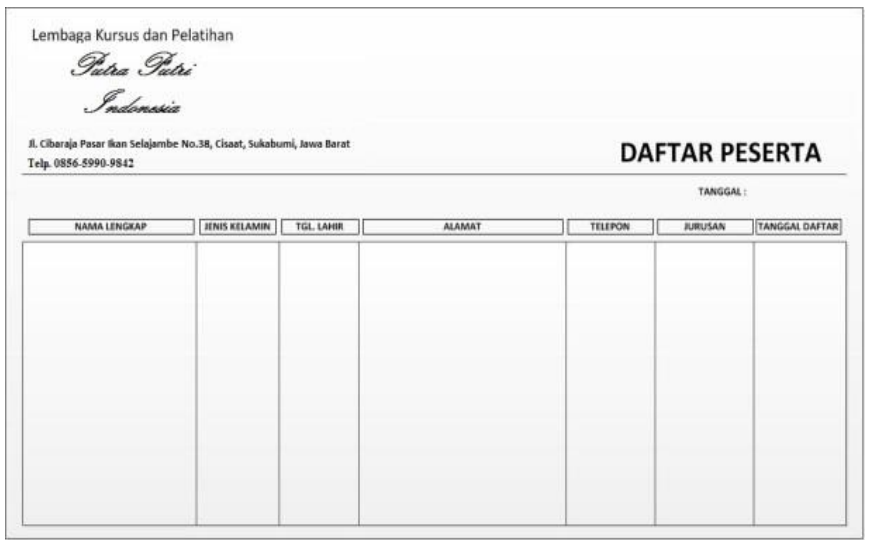

Gambar 13. Daftar Peserta Kursus

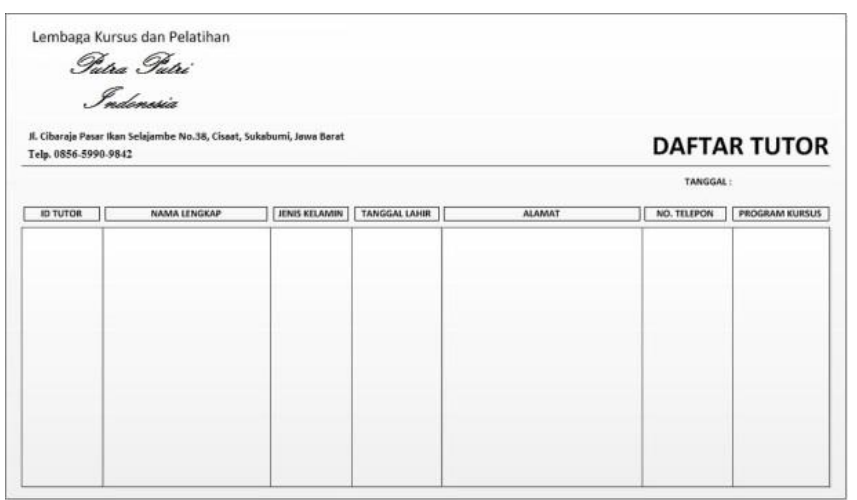

Gambar 14. Daftar Tutor

\section{j. Perancangan Model Arsitektur Jaringan}

Pada perancangan model arsitektur jaringan komputer untuk mendukung penerapan pada sistem informasi yang dibangun, yaitu menggunakan arsitektur jaringan Local Area Network (LAN) dengan topologi Star. Alasan pemilihan alternatif topologi yaitu untuk memberikan kemudahan pada proses penanganan permasalahan jaringan dan kemudahan dalam pendefinisian jalur untuk setiap client (Ginta et al., 2015). Berikut adalah model arsitektur jaringan untuk 
penerapan sistem informasi pada LKP3I, seperti tertuang pada gambar 15 dibawah ini:

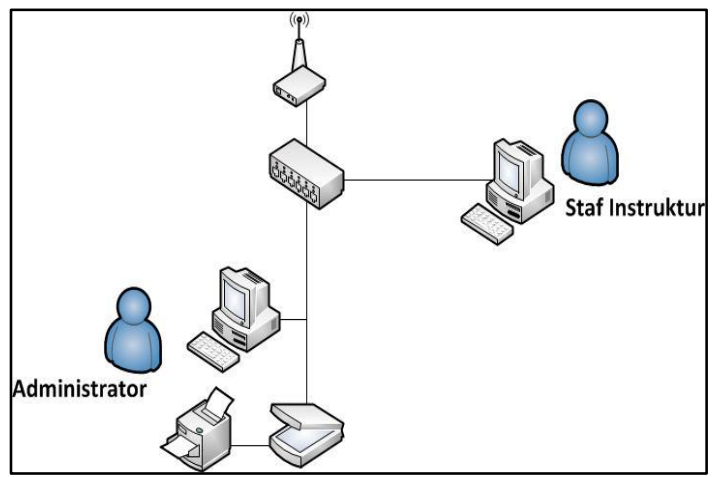

Gambar 15. Model Arsitektur Jaringan Usulan

\section{k. Implementasi Antarmuka Aplikasi}

Antarmuka merupakan bagian penting dalam pembangunan sistem (Karpen, 2012) pengelolaan data administrasi LKP3I serta mengacu kepada elisitasi dimana kebutuhan pengguna terhadap antarmuka aplikasi yaitu kemudahan dalam penggunaan atau akses, dan kecepatan respon aplikasi. Berikut adalah daftar implementasi antar muka pembangunan prototipe aplikasi:

\section{1) Form Login}

Form Login menampilkan pengisian username dan password. form ini dikhususkan untuk login admin.

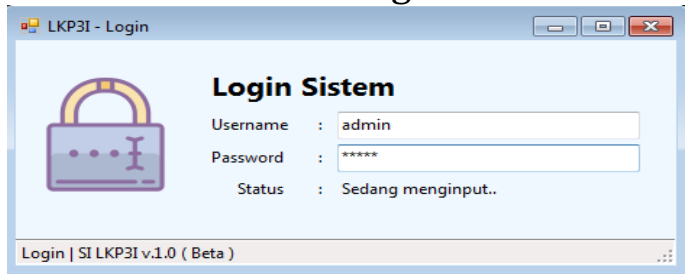

Gambar 16. Form Login

\section{2) Halaman Utama}

Halaman utama berisi menu pendaftaran, data peserta, data tutor atau instruktur, data jurusan, transaksi, dan laporan.

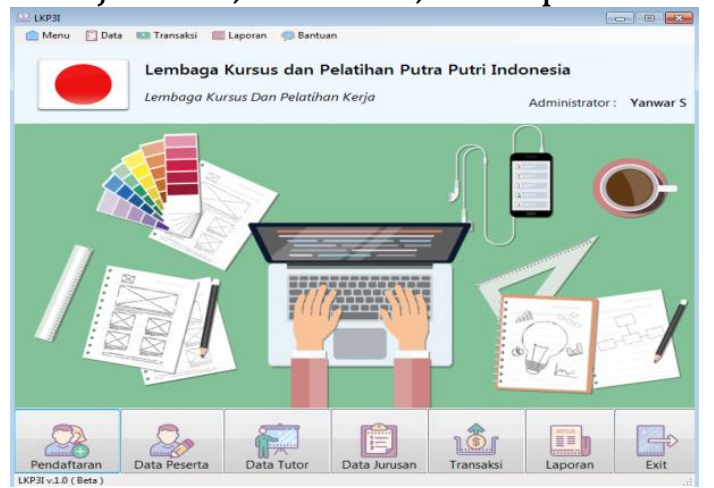

Gambar 17. Halaman Utama

\section{3) Halaman Pendaftaran}

Halaman pendaftaran berisi keterangan transaksi pendaftaran calon peserta, mengenai jurusan yang diambil, jurusan dan detail paket program dan detail proses pmbayaran. 


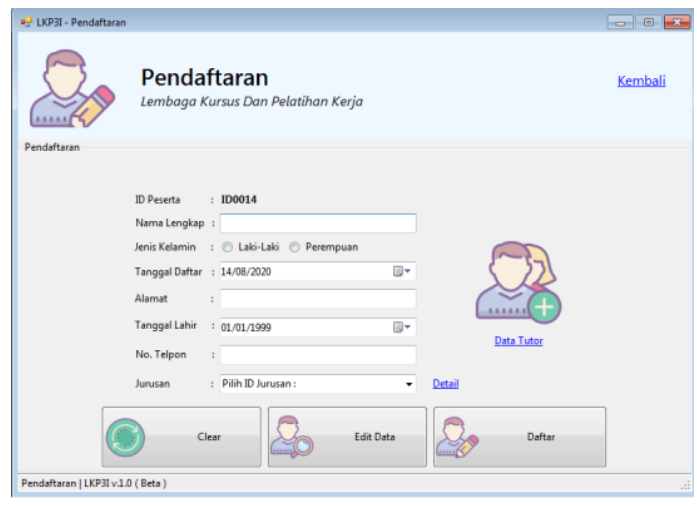

Gambar 18. Halaman Pendaftaran

\section{4) Halaman Daftar Peserta}

Halaman daftar peserta berisi identitas peserta, status pembayaran, dan program kursus yang diambil pada LKP3I. pada halaman ini administrator dapat menambah, mengedit, menghapus, dan melakukan pencarian data dalam sistem.

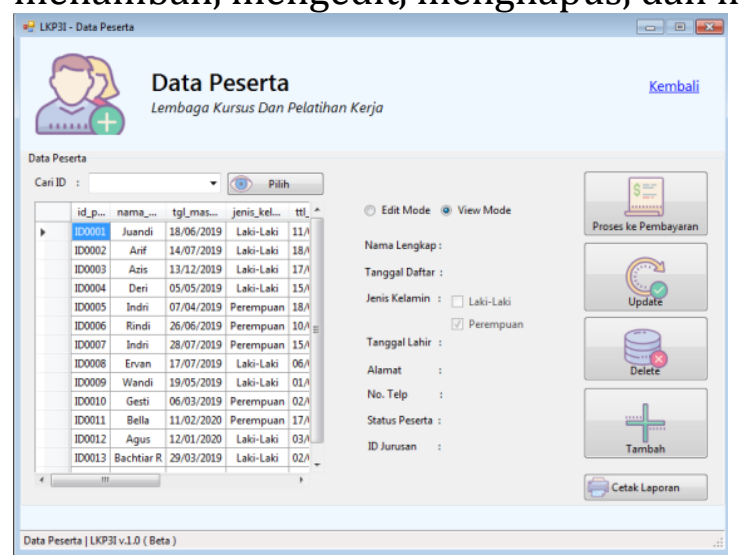

Gambar 19. Halaman Daftar Peserta

\section{5) Halaman Data Tutor atau Instruktur}

Halaman ini berisi halaman identitas tutor atau instruktur yang mengajar pada LKP3I.

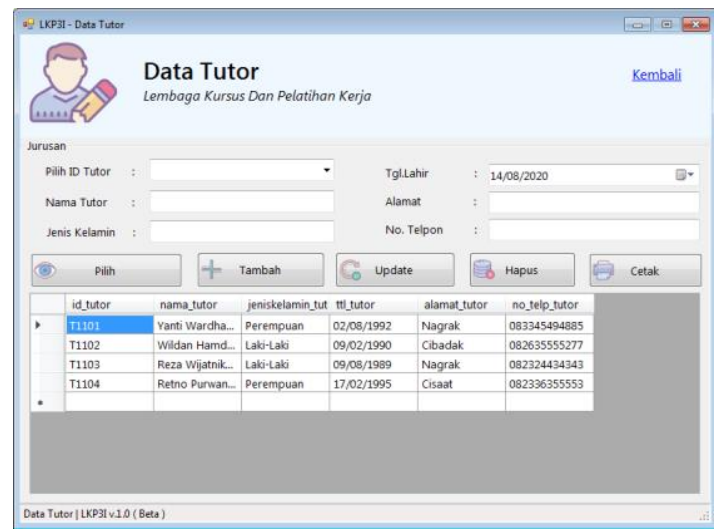

Gambar 20. Halaman Data Tutor

\section{6) Halaman Jurusan}

Halaman ini berisi data jurusan yang ada di LKP3I, pada halaman ini administrator dapat menambah, mengedit, dan menghapus data dalam sistem. 


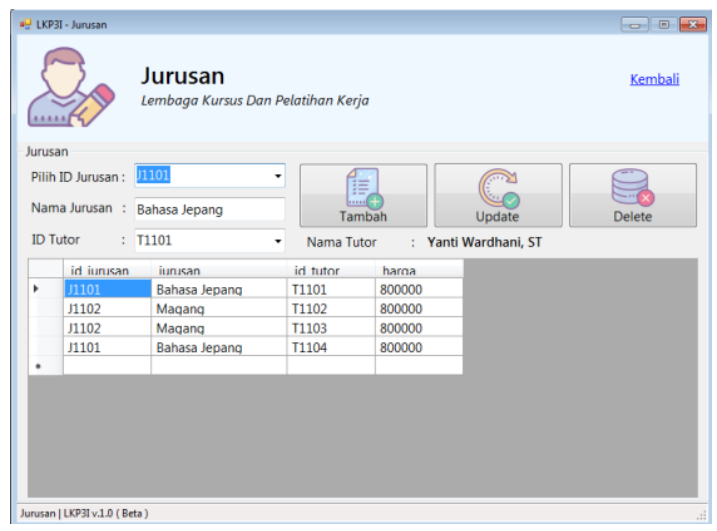

Gambar 21. Halaman Data Jurusan

\section{7) Halaman Transaksi Pembayaran}

Halaman ini berisi data transaksi pembayaran peserta LKP3I, pada halaman ini administrator dapat menambah, mengedit, menghapus, dan melakukan pencarian data dalam sistem.

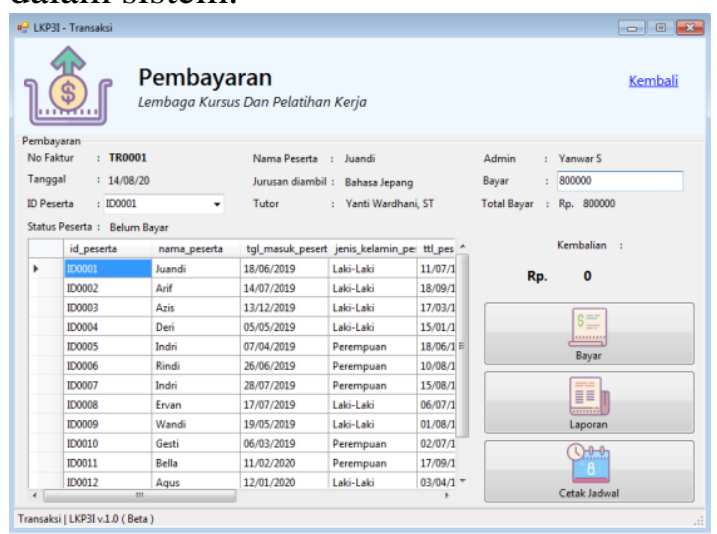

Gambar 22. Halaman Data Transasksi Pembayaran

\section{8) Halaman Laporan Pembayaran}

Halaman ini berisi data transaksi pembayaran peserta LKP3I yang sudah melakukan transaksi pembayaran, pada halaman ini administrator dapat menghapus dan mencetak laporan data dalam sistem.

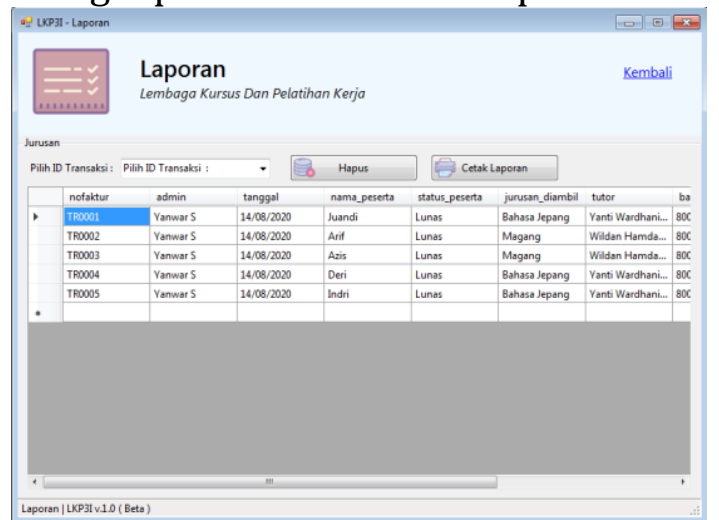

Gambar 23. Halaman Transasksi Pembayaran 


\section{9) Laporan Daftar Peserta}

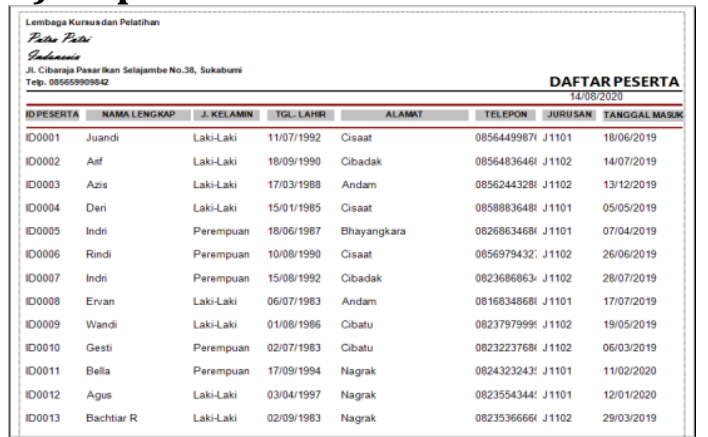

Gambar 24. Laporan Peserta

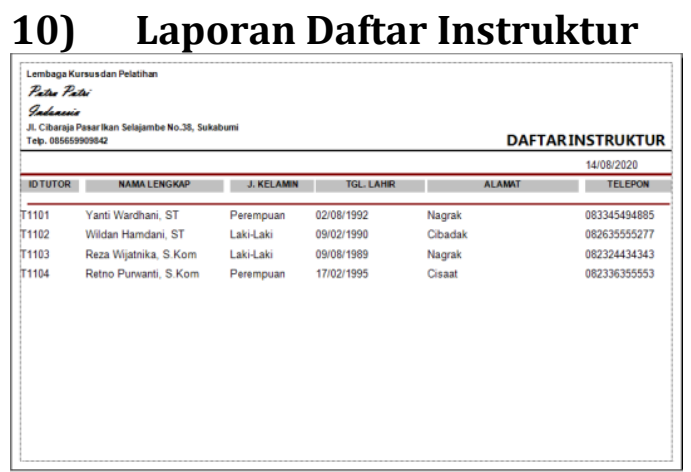

Gambar 25. Laporan Daftar Instruktur

\section{1) Laporan Transaksi Pembayaran}

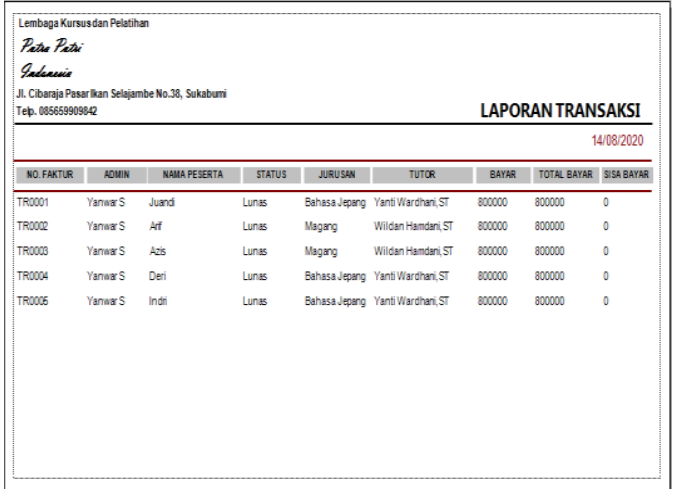

Gambar 26. Laporan Transaksi Pembayaran

\section{Pengujian Sistem}

\section{1) Pengujian BlackBox}

Pada tahapan pengujian fungsional prototipe sistem informasi administrasi pendidikan LKP3I, bahwa hasil pengujian berdasarkan skenario dan ekspektasi hasil menunjukan tidak adanya kegagalan dan mendekati spesifikasi kebutuhan pengguna.

\section{2) Evaluasi sistem (Pengguna)}

Evaluasi sistem dilakukan berdasarkan pendekatan elisitasi dalam pengembangan sistem informasi administrasi pendidikan pada LKP3I, dimana proses akhir dari tahapan penelitian ini adalah uji validasi prototipe hasil oleh pengguna dalam rangka melihat kesesuaian antara keinginan pengguna dengan produk yang dihasilkan. Adapun teknik yang digunakan dalam evaluasi sistem 
adalah teknik diskusi grup. Berdasarkan hasil diskusi yang telah dilakukan di LKP3I, hasil rekapitulasi evaluasi sistem seperti tertuang pada Tabel 2 berikut:

Tabel 2. Hasil Tanggapan Responden

\begin{tabular}{l|l}
\hline Nama Responden & : Budi Rahmat \\
\hline Jabatan & $\begin{array}{l}\text { : Humas LKP3I (Perwakilan Stakeholder Prototipe } \\
\text { Aplikasi) }\end{array}$ \\
\hline Tanggal & $: 10$ Agustus 2020 \\
\hline
\end{tabular}

Hasil tanggapan responden dalam wawancara

1. Bagaimana pendapat Anda mengenai prototipe sistem pengelolaan data administrasi LKP3I yang dibangun berkenaan dengan realisasi input dan output yang dihasilkan?

\section{Tanggapan Responden}

Tanggapan responden berkenaan dengan input output prototipe sistem pengelolaan data administrasi LKP3I yang dihasilkan cukup baik, tetapi perlu penyempurnaan dengan alasan masih ada kekurangan dari sisi fitur dan konten.

2. Apakah prototipe sistem prototipe sistem pengelolaan data administrasi LKP3I yang dibangun mudah dalam penggunaan?

\section{Tanggapan Responden}

Responden berpendapat bahwa prototipe sistem pengelolaan data administrasi LKP3I yang dihasilkan mudah dalam penggunaannya, tetapi perlu disederhanakan kembali seperti halnya menu cetak untuk pelaporan pembayaran yang memiliki banyak jalur akses, yang seharusnya mampu untuk mengadaptasi tren model seperti contoh "single sign on".

3. Bagaimana pendapat Anda dengan sistem pelaporan pada prototipe sistem pengelolaan data administrasi LKP3I yang dihasilkan?

\section{Tanggapan Responden}

Responden berpendapat bahwa sistem pelaporan dari prototipe yang dibangun sudah cukup baik, dengan alasan karena sudah tepat menggunakan crystal report atau aplikasi pihak ketiga yang sudah pasti untuk fungsi dan peruntukannya.

4. Bagaimana pendapat Anda dengan sistem manajemen basis data yang digunakan pada pembangunan prototipe sistem pengelolaan data administrasi LKP3I yang dihasilkan?

\section{Tanggapan Responden}

Responden menilai bahwa sistem manajemen basis data yang digunakan cukup baik, tetapi akan lebih baik lagi jika menggunakan aplikasi sistem manajemen basis data yang memiiliki daya tampung yang lebih besar seperti halnya oracle atau minimal dipadukan dengan SQL Server.

5. Bagaimana pendapat Anda berkenaan dengan waktu respon dari penggunaan prototipe sistem pengelolaan data administrasi LKP3I yang dihasilkan?

\section{Tanggapan Responden}

Responden berpendapat bahwa waktu respon dalam penggunaan prototipe sistem informasi yang dihasilkan sudah cukup baik dalam menampilkan informasi.

\section{SIMPULAN DAN SARAN}

Berdasarkan hasil penelitian dengan menggunakan teknik pendekatan elisitasi mendapatkan penilaian yang cukup baik dengan mengacu pada hasil evaluasi pengguna, 
dengan mempertimbangkan bahwa kondisi sistem yang ada saat ini belum memilki pengelolaan basis data.

Berdasarkan hasil penelitian yang telah dilaksanakan juga, maka penulis memberikan saran dan masukan:

1. Hasil pengembangan sistem selanjutnya diharapkan dapat menyempurnakan kembali secara lebih baik dan komprehensip yang mencakup seluruh proses pengolahan data pada semua bagian.

2. Penulis menyadari masih banyak kekurangan dalam pembuatan program ini, dikarenakan kemampuan yang penulis miliki. Oleh karena itu, agar lebih efektif dimasa akan datang diharapkan program aplikasi dapat lebih dikembangkan dengan berbasis jaringan Client-Server.

\section{REFERENSI}

A, D., A, V., S, F., \& S, S. (2013). Peranan Teknologi Komunikasi dalam Menciptakan Masyarakat Informasi di Indonesia. Jurnal ILMU KOMUNIKASI, 1. https://doi.org/10.24002/jik.v1i1.159

Azis, A. dan S. (2018). Aplikasi Ekspedisi Barang Di PT. Karya Indah Buana Tasikmalaya. Jumantaka.

Ginta, P. W., Kusuma, G. P., \& Negara, E. K. (2015). Implementasi Tools Network Mapper Pada Lokal Area Network (LAN). Media Infotama, 9.

Karpen, K. (2012). Antarmuka sebagai Media Komunikasi dengan Sistem. Sains Dan Teknologi Informasi, 1(2), 106-110. https://doi.org/10.33372/stn.v1i2.329

Kurniawan, K. (2018). Tahap-Tahap Pengembangan Sistem Informasi.

Muchdie, M. (2016). Economic Growth, Human Development and Global Competitiveness. International Journal of Social Science and Economic Research, 01, 1718-1735.

Muhammad Syahrul Ramadhan. (2020). Pendidikan Berkualitas Solusi Perbaiki Daya Saing. https://www.medcom.id/pendidikan/news-pendidikan/VNnXaBjk-pendidikan-berkualitas-solusiperbaiki-daya-saing

Nugroho, P. S., \& Sofyan, A. F. (2011). Perancangan Media Pembelajaran Berbasis Multimedia untuk Dasar-dasar Pembuatan Animasi 2d Menggunakan Macromedia Flash Mx 2004. Data Manajemen Dan Teknologi Informasi, 12(4).

PRASTOMO, A. (2015). Prototipe Sistem E-Learning Dengan Pendekatan Elisitasi Dan Framework Codeigniter: Studi Kasus Smp Yamad Bekasi. Faktor Exacta. https://doi.org/10.30998/FAKTOREXACTA.V7I2.257

Prastya, A. P., Prastya, R., Akuntansi, J., Ekonomi, F., Bisnis, D., Mercu, U., Jl, B., Meruya, S., No, Kembangan, J., \& Barat. (2020). Artikel Sistem Informasi Pada Suatu Perusahaan. Jurnal Sistem Informasi Bisnis, $1,5$.

Rachmanto, A. (2017). Sistem Informasi Akuntansi Penjualan Perusahaan Dagang. Jurnal Riset Akuntansi. https://doi.org/10.34010/jra.v5i1.506

Schwab, K. (2019). Global Competitiveness Report 2019| World Economic Forum. World Economic Forum.

Solikhin, I., Sobri, M., \& Saputra, R. (2018). Sistem Informasi Pendataan Pengunjung Perpustakaan (Studi Kasus: SMKN 1 Palembang). Jurnal Ilmiah Betrik, 9(03), 140-151. https://doi.org/10.36050/betrik.v9i03.40

Sugandi, L. (2014). Pengaruh Teknologi Informasi untuk Meningkatkan Pelayanan dalam Proses Belajar Mengajar. ComTech, 5(2), 939-953.

wahyu timortiingsih, E. (2011). Sistem Informasi Pengolahan Data Perpustakaan pada Smk Negeri 1 Demak. Tatal, 6(2).

Wijaksana, T. I. (2015). Analisis Faktor - Faktor Sistem Informasi Manajemen Di PT. Cimb Niaga Tbk Cabang Bandung. Jurnal Bisnis Darmajaya, 1(01), 127-135. 